\title{
To feel with and for Friedrich Schleiermacher: On religious experience
}

\begin{tabular}{|c|c|}
\hline $\begin{array}{l}\text { Author: } \\
\text { Daniël P. Velds }\end{array}$ & $\operatorname{man}^{1}$ (D) \\
\hline $\begin{array}{l}\text { Affiliation: } \\
{ }^{1} \text { Department } \\
\text { and Historical } \\
\text { Faculty of The } \\
\text { Religion, Univ } \\
\text { Pretoria, Pretc } \\
\text { South Africa }\end{array}$ & $\begin{array}{l}\text { f Systematic } \\
\text { Theology, } \\
\text { ology and } \\
\text { ersity of } \\
\text { ria, }\end{array}$ \\
\hline $\begin{array}{l}\text { Research Proj } \\
\text { Project Leader } \\
\text { Project numb }\end{array}$ & $\begin{array}{l}\text { ect Registration } \\
\text { : D.P. Veldsman } \\
\text { er: } 01224719\end{array}$ \\
\hline $\begin{array}{l}\text { Project Descri } \\
\text { Dr Steenkamp } \\
\text { in the researcl } \\
\text { 'Religious Exp } \\
\text { an evolutionar } \\
\text { directed by Pr } \\
\text { Veldsman, De } \\
\text { Dogmatics anc } \\
\text { Ethics, Faculty } \\
\text { University of P }\end{array}$ & $\begin{array}{l}\text { ption: } \\
\text { is participating } \\
\text { project, } \\
\text { erience from } \\
\text { y perspective', } \\
\text { of. Dr Danie } \\
\text { partment } \\
\text { Christian } \\
\text { of Theology, } \\
\text { retoria. }\end{array}$ \\
\hline $\begin{array}{l}\text { Correspondin } \\
\text { Daniël Veldsm } \\
\text { danie.veldsma }\end{array}$ & $\begin{array}{l}\text { g author: } \\
\text { an, } \\
\text { n@up.ac.za }\end{array}$ \\
\hline $\begin{array}{l}\text { Dates: } \\
\text { Received: } 021 \\
\text { Accepted: } 21 \\
\text { Published: } 30\end{array}$ & $\begin{array}{l}\text { May } 2019 \\
\text { May } 2019 \\
\text { July } 2019\end{array}$ \\
\hline $\begin{array}{l}\text { How to cite th } \\
\text { Veldsman, D.P } \\
\text { with and for F } \\
\text { Schleiermach } \\
\text { experience', H } \\
\text { Studies/Theolc } \\
75(4) \text {, a5537. } \\
\text { 10.4102/hts.v }\end{array}$ & $\begin{array}{l}\text { is article: } \\
\text {, 2019, 'To feel } \\
\text { iedrich } \\
\text { r: On religious } \\
\text { TS Teologiese } \\
\text { gical Studies } \\
\text { tttps://doi.org/ } \\
75 i 4.5537\end{array}$ \\
\hline $\begin{array}{l}\text { Copyright: } \\
\text { (C) 2019. The A } \\
\text { Licensee: AOS } \\
\text { is licensed unc } \\
\text { Creative Comr } \\
\text { Attribution Lic }\end{array}$ & $\begin{array}{l}\text { uthors. } \\
\text { S. This work } \\
\text { ler the } \\
\text { nons } \\
\text { ense. }\end{array}$ \\
\hline Read online: & \\
\hline 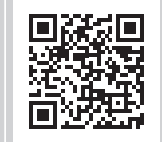 & $\begin{array}{l}\text { Scan this QR } \\
\text { code with your } \\
\text { smart phone or } \\
\text { mobile device } \\
\text { to read online. }\end{array}$ \\
\hline
\end{tabular}

The German systematic theologian Friedrich Schleiermacher has shaped Western Christian theological thinking in many ways. One such influential way has been his formulation and exposition of religious experience, and specifically the concept of the 'feeling of absolute dependence' (Gefühl der schlechthinnigen Abhängigkeit). From a brief account of his understanding of the 'feeling of absolute independence', a few critical remarks are made from the broader context of contemporary hermeneutical discourses, focusing on the constitutive role of affectivity and narrative identity in religious experiences of embodied personhood. It is argued that these two themes in revisiting Schleiermacher's understanding of the 'feeling of absolute dependence' can contribute to a more comprehensive understanding of religious experience.

Keywords: Schleiermacher; Religious experience; Feeling of absolute dependence; Affectivity; Narrative identity; Embodied personhood.

\section{Introduction}

There are very good reasons why the German philosopher, theologian and biblical scholar Friedrich Daniel Ernst Schleiermacher (1768-1834) is one of the scholars who is included in the well-known series Makers of the modern theological mind..$^{1}$ Of this series, the editor Bob Patterson writes on the back cover:

Who are the thinkers that have shaped Christian theology in our time? This series tries to answer that question by providing a reliable guide to the ideas of the men who have significantly charted the theological seas of our century.

Leaving the unquestioned sexist note on 'the thinkers that have shaped Western Christian theology ... (as - DV) ... the ideas of men' by Patterson aside for the moment, I turn to Schleiermacher who has shaped Western Christian theological reflection in our time in many ways. He has indeed significantly chartered the Western theological seas of our century as Patterson puts it. In my engagement with Schleiermacher, I will focus only on one concept - in my mind a very important concept - that he has influentially utilised in the 19th century for our wideranging interpretations of religious experience. This concept is, namely, the 'feeling of absolute dependence' (Gefühl der schlechthinnigen Abhängigkeit). Before I turn to a brief account of his understanding and exposition of the concept that I have chosen as the focus for the article, a few introductory remarks should suffice to sketch in broad outlines the hermeneutical-theological context of his contribution:

- Schleiermacher is perhaps best known for his philosophical-theological efforts in bringing together the radical criticism flowing relentlessly from the Enlightenment with traditional Protestant Christianity. His bringing together of the two finds integrated expression in especially his hermeneutics and understanding of religion. ${ }^{2}$ His philosophical-theological efforts, however, have brought about a wide range of Schleiermacherian labelling from the 'Father of Modern Liberal Theology'3 to 'heretic'. ${ }^{4}$

- His best-known works are Über die Religion. Reden an die Gebildeten unter ihren Verächtern (On Religion: Speeches to Its Cultured Despisers, 1799) and Der christliche Glaube (The Christian

1.The latest addition in September 2017 to the series is on Hans Küng, written by the late Dutch-American historian John J. Kiwiet (1925-2006).

2. His integrating efforts are viewed by some - especially the German philosopher Hegel - in a rather negative light, seeing 'his cure as far worse than the disease'. See Stewart (2018) for a good exposition of Hegel's criticism of Schleiermacher's efforts.

3.In his Contemporary theology: An introduction, MacGregor (2019) sketches in broad outlines his understanding of Schleiermacher as founder of liberal theology, especially with regard to Schleiermacher's viewpoint on Christology.

4.For but one very recent and interesting example of such Schleiermacherian labelling, see the article by Joel Daniels (2018) Friedrich Schleiermacher: Pentecostal Friend or Foe?

Note: Engaging Schleiermacher today: South African perspectives, sub-edited by Rian Venter (University of the Free State).

Paper read in Oct 2018 at Schleiermacher Seminar, University of Free State, Bloemfontein 
Faith, 1821-22). In the former, he directs his theological concern to those people who had turned their backs on religion for many good reasons and were seeking alternatives; in the latter, he seeks to explicate Christian faith to believers who wanted to understand their faith in the period following the Enlightenment.

- A very wide range of intellectual influences (from Von Schlegel, Leibnitz, Lessing, Jacobi, Spinoza, Kant, Fichte, Schelling) can be noted on his work of which the German philosopher, theologian, poet and literary critic Johann Gottfried von Herder (1744-1803) was surely the most important.

In what follows, I would like to focus firstly on a brief account of his understanding of the 'feeling of absolute independence', and secondly to make a few critical remarks within the broader context of contemporary hermeneutical discourses that relate to the concept.

\section{Feeling}

How is religion (or religious experience) to be understood? If then described in terms of feeling, how is 'feeling' to be understood?

Schleiermacher (cf. 1830) firstly qualifies in his exposition of religion that 'what is to follow' implies diversity of expression (community) and sameness (individual) in the following way:

However diverse they might be, what all the expressions of piety have in common, whereby they are at the same time distinguished from all other feelings - thus the selfsame nature of piety - is this: that we are conscious of ourselves as absolutely dependent or, which intends the same meaning, as being in relation with God. (p. 18)

For Schleiermacher, religious experience (as 'feelings of piety') is not founded either on intellectual doctrinal beliefs or on the acceptance of moral principles. In addition, its core is also not in the first place to be understood as thinking or acting. It is to be taken as intuition (i.e. an immediate non-conceptual engagement with the universe as its object) ${ }^{5}$ and feeling (i.e. the subjective affective tone which follows in the wake of such apprehension). The two are inseparable, although they can be separated in reflecting on their significance. From here, Schleiermacher moves to an introduction of the concept of 'absolute dependence' which is present and innate in every person. He acknowledges his indebtedness to Professor Delbrück for the adjective 'absolute' (schlechthinnigen). For Schleiermacher, the relationship to God can be described as a 'Gefühl der schlechthinnigen Abhängigkeit', that is, a feeling of absolute dependence that is situated in the immediate, prereflective consciousness. Perhaps more aptly formulated and explained: it is an immediate self-awareness that becomes an

5.In their interesting book on Cosmic Consciousness and Human Excellence Implications for Global Ethics, the editors in their Introduction to cosmic consciousness and the soul talk about Schleiermach consciousness and the soul talk about Schleiermacher - in following Spinoza - as one of the advocates of cosmic-conscious ariculations .... (Masaeli \& Sneller faith is . Ind this a very apt and helpful description so that his understanding of faith is not mistakenly confused with a mere emotional approach to religious experience. Regarding the latter confusion, see especially Reed (2005), Stoke (2006), Roberts (2016) and Scarantino (2018). awareness of God. An immediate awareness of dependence of a particular nature that is called the feeling of absolute dependence. What does the 'particular nature' refer to? For Schleiermacher, it represents a 'one-ness' with the infinite in the midst of the finite. The 'particular nature' is characterised as 'Sinn und Geschmack für das Unendliche', that is, a sense (or sensibility) and taste for the Infinite. ${ }^{6}$ The 'whence' of this feeling of absolute dependence is identified as God (cf. Schleiermacher 1830:24). It is a consciousness that is characterised by both receptivity and self-initiated activity, that is the feeling of dependence and of freedom that co-exist in temporal self-consciousness (cf. Schleiermacher 1830:20-21).

\section{He elaborates on religion as feeling, stating:}

Religion is to seek this and find it in all that lives and moves, in all growth and change, in all doing and suffering. It is to have life and to know life in immediate feeling, only as such an existence in the Infinite and Eternal. (Schleiermacher 1799:36)

And more descriptive:

... true religion is sense and taste for the Infinite. (Schleiermacher 1799:39)

Religion, or perhaps better understood in this context as 'religious experience', is - on the one hand - not to be seen as mere 'knowing'. That would be precisely that which he would like to protest against, namely the rational approach of doctrinal orthodoxy. On the other hand, religion is also not simply 'doing'. That would reduce religion to morality. In this sense, consciousness precedes knowledge and action. Schleiermacher (1830) states:

The piety that constitutes the basis of all ecclesial communities regarded purely in and of itself, is neither a knowing nor a doing but a distinct formation of feeling, or of immediate selfconsciousness. (p. 8)

Over against the No on both accounts, that is, to 'mere knowing' and 'morality', religious experience is explicated as an interior, personal experience with an element of the unknowable and the mysterious. In The Christian Faith, Schleiermacher (1830) goes on to say:

The feeling of absolute dependence, accordingly, is not to be explained as an awareness of the world's existence, but only as an awareness of the existence of God, as the absolute undivided unity. (p. 32)

As experience (that can in this very sense be called a Godconsciousness), it will find expression within a specific religious context in a definite form. As human beings that are social creatures, our expressed feelings are subsequently concrete.

6.In his discussion of Schleiermacher and his understanding of religious experience Keith Ward (2019:96) in his Religion in the modern world has assisted me with his specific explanation of Schleiermacher's 'Sinn und Geschmack für das Unendliche' in specific explanation of Schleiermacher's 'sinn und Geschmack fur das Unendliche in writing: $\ldots[$ [ [ t seems that the infinite and eternal is seen in and through things that are infinite and temporal. Instead of thinking of an apprehension of a separate reality, the infinite, we can think of finite things, which we apprehend as mediating a sense of the infinite, the whole, the independent, the eternal. The "sensibility an taste for the infinite" is a capacity to sense the finite as a "representation of the infinite"'. An insightful South African exposition of Schleiermacher's 'feeling of absolute dependence' can be found in Mouton (1990). 
And he continues:

Every religious and Christian self-consciousness presupposes and thus also actually contains the immediate feeling of absolute dependence, as the only way in which, in general, one's own being and the infinite being of God can be one in selfconsciousness. (Schleiermacher 1830:33)

This feeling of absolute dependence, in which our selfconsciousness in general represents the finitude of our being, is therefore not an accidental element, nor a thing which varies from person to person, but is a universal element of life $^{7}$; and the recognition of this fact entirely takes the place, for the system of doctrine, of all so-called proofs of the existence of God.

\section{Critical remarks}

Limiting myself to Schleiermacher's concept of 'absolute dependence' but broadening its significance to a number of related contemporary discourses, I tentatively would like to pose the following critical comments.

For me, Schleiermacher has opened up in his understanding and explication of religion and religious experience (as 'Sinn und Geschmack für das Unendliche') a broader understanding of rationality that I find convincing and very intriguing that I would pursue today within theology-science discourses, especially in relation to evolutionary biological discourses. Feeling - as immediate awareness, as consciousness - finds very apt evolutionary biological expressions. To name but one example from the field of the neuro-scientific example. In the classic work The Feeling of What Happens (1999) of the Portuguese-American neurobiologist Antonio Damasio, he describes consciousness in the shortest phrase possible as the 'feeling that something happens'. Feeling is here not be understood or confused with 'emotions'. Emotions follow from the basic description of 'feeling' as consciousness which then subsequently finds concrete physiological expression in emotions. ${ }^{8}$ But back to Schleiermacher. The 'feeling' as an $a$ priori ontological statement regarding God-consciousness and 'absolute dependence', however, are in its interpretative unfolding by Schleiermacher in many ways promising but at the very same time problematic. The broadening of our understandings of rationality and also his effort to overcome the strong boundaries of individualism are promising. However, from contemporary hermeneutical insights such as the theory-ladenness of all experience, that is, that all experiences are interpreted experiences, it follows that no religious experience can be pre-linguistic. The experience as such is concretely and existentially 'at home' within a specific language tradition. God-consciousness finds expression as a

7.In this sense, Schleiermacher breaks open, on the one hand, an understanding of religion as a universal or global human phenomenon, but at the same time he argues, on the other hand, that Christianity represents religion par excellence.

8.See as example the exposition on Schleiermacher by the Hungarian philosopher Mezei (2019:55ff.) in which he - in his discussion of models for the character of faith - talks about an emotional model, that is, a model in which the "traditional understanding of faith "reality" and "evidence" gives way to the model of emotional experience, in which "feeling" appears as a separate faculty of human beings to perceive God" which "feeling" appears as a separate faculty of human beings to perceive God'
(Mezei 2019:62). Schleiermacher's understanding of 'feeling' is here, in my opinion, (Mezei 2019:62). Schleie
confused with emotion. conceptualised experience. And to the constitutive importance of all experiences as theory-laden, I will add affectivity because no experience is possible without being permeated by affectivity. ${ }^{9}$ Affectivity is not some kind of irrational 'add-on' that should be avoided at all rational cost. It is a biological given: our biological roots determine human rationality. ${ }^{10}$ We are woven together by neurons and blood vessels, and these constitutive elements of our bodily communicative systems determine our rational-existential engagements with realities. Religious experience in this sense, that is, as rational-existential engagements with realities, is a cognitive-affective experience. Perhaps better formulated in an oversimplified way: in the spelling out of the meaning of life by embodied persons, the vowels are represented by affectivity (i.e. the biological-existential glue that keeps everything together) and the consonants by cognitivity - and the two cannot be separated in our engagement with reality and its subsequent sense-making activities. The French mathematician, physicist, inventor, writer and Catholic theologian Blaise Pascal (1623-1662) had it right - in my opinion now re-interpreted and understood from contemporary evolutionary biological insights - when he said in his own lively formulation of religious experience almost 150 years before Schleiermacher that the heart has indeed reasons of which reason itself is not even aware! In an evolutionary biological (rational) sense-making framework, his remark makes sense today. Metaphorically translated into religious experiential terms: we love God with our hearts, not our heads, and therefore all knowledge of God is affective knowledge. ${ }^{11}$

But Schleiermacher's depiction and unfolding of Godconsciousness - as universal phenomenon - also becomes problematic in another sense when taken up in our postmodern contexts of pluralism (and therefore, of pluralistic understandings of religions). It is no longer hermeneutically possible and acceptable, as was perhaps not problematised in his religious-historical context, to work with, or take for granted a Christian religious 'Selbstverständlichkeit' so that the 'whence' of the 'Gefühl' could simply be understood as being that of the God of Christianity. Such a position can no longer be defended uncritically.

The 'whence' has to be taken up interpretatively within the context of embodied personhood, that is, can only be

9.My argument, and the very reasons for the emphasis on affectivity, is neatly and concretely illustrated in a very recent article From religious emotions to affects: historical and theoretical reflections on injury to feeling, self and religion by Ural and Berg (2019) in which they reflect on the significance of affect as conceptual Berg (2019) in which they reflect on the significance of affect as conceptual
alternative - in reference to the writing of Schleiermacher among others - to "how alternative - in reference to the writing of Schleiermacher among others - to 'how
religion and feeling have become inextricably intertwined, located within the religion and feeling have become inextricably intertwined, located within the
individual self and institutionalised as a dominant interpretation of religion'. In an insightful manner, Ural and Berg (2019) addresses the 'images of angry Muslims' in which they challenge the trope of hurt religious feelings in the explanation of unrest. For a detailed exposition of my own emphasis and understanding of the role of affectivity, see Veldsman (2014).

10.Although our biological roots determine human rationality, it does not imply in an unqualified sense that we do not transcend our roots in our sense-making activities of reality. The constitutive relatedness with our biological roots has been an illuminating contribution of contemporary evolutionary epistemological discourses for our models on rationality.

11.The metaphoric description is, however, open for misinterpretation - as if our 'heads' (minds) are now put 'out of interpretative play'. Perhaps the metaphoric description can be alternatively formulated as 'loving God with our heads that are wrapped by our hearts'! 
formulated from the very different sense-making frameworks of the narrative identities of those who are witnessing the 'whence' of their specific religious experience. For me, the concept narrative identities ${ }^{12}$ captures the concrete historical-existential framework from which embodied persons within a specific linguistic-social tradition undertake their respective sense-making activities. Formulated in religious terms: our various witnesses to transcendence tell the stories from where we are configuratively and re-figuratively giving content (i.e. conceptualising within a given linguistic tradition) and making sense of the 'whence' of our religious experiences.

Another problematic development however which, in my opinion, does not do justice to Schleiermacher's concept of feeling is the numerous engagements (especially psychological discourses) with feeling as if we have to primarily understand it from theories on religious emotions. My understanding of his conceptualisation of feeling as prereflective consciousness is that it represents an a priori ontological statement with its emotive expressions to follow on that which to him is neither knowing nor doing, but intuition. This represents to me a confusing conflation of an ontological statement with a physiological trait of embodied personhood. Schleiermacher's 'feeling' is better understood and developed when explicated from evolutionary perspectives as consciousness in terms of a human capacity for imagination, symbolic thought and creativity. And from here flows a strong impetus for the subsequent broadening of our understandings of human rationality with the inevitable inclusion of affectivity.

\section{Conclusion}

In the Introduction, it was stated that Schleiermacher is perhaps best known for his philosophical-theological efforts in bringing together the radical criticism flowing relentlessly from the Enlightenment with traditional Protestant Christianity. It is precisely his historical-contextual dated efforts that - in my opinion - in terms of mapping and not so much territory (to use the helpful term by the well-known philosopher of religion Jonathan Z. Smith) that is of great importance for our ongoing theological efforts. Now, however, the historical dated face of the 18th century's Enlightenment criticism finds many new expressions in the 21st-century discourses on post-modernism, the sciencetheology dialogue, the Fourth Industrial Revolution: all deep probing and radical challenges in our pluralistic - and specifically African - contexts if that has to be brought together with our contemporary understandings of Godconsciousness, of Christian faith to our own respective generations of despisers and believers. Schleiermacher's

12.My critical emphasis on narrative identities has indirectly been inspired by Wolfe's (2019:56ff.) discussion of the German philosopher of Religion, Ernst Troeltsch (1865-1923) in her The Eschatological Turn in German Philosophy. She mentions that 'Troeltsch is here revising Schleiermacher in an eschatological direction. His is a feeling of absolute dependence experienced through time, an absolute dependence on religious intuition for the direction of an individual's life, not for his or her immediate position'. The key for me here is the word 'revising' which I subsequently do not take as a revision, but as necessary interpretative addition and broadening of do not take as a revision, but as necessary interpretative addition and broadening of
the constitutive contextuality of an understanding of the concept of 'absolute the constitutive
dependence'. contribution after 250 years is still to be taken seriously as insightful 'mapping' because it shows possible ways of configurations and re-figurations for addressing these very challenges in our cognitive-affective longing to bring them together as responsible account for the hope that lives within us. In this qualified sense, I feel with and for Schleiermacher.

\section{Acknowledgement Competing interest}

The author declares that no competing interest exists.

\section{Author contributions}

I declare that I am the sole author of this research article.

\section{Funding}

This research received no specific grant from any funding agency in the public, commercial, or not-for-profit sectors.

\section{Data availability statement}

Data sharing is not applicable to this article as no new data were created or analysed in this study.

\section{Disclaimer}

The views and opinions expressed in this article are those of the authors and do not necessarily reflect the official policy or position of any affiliated agency of the authors.

\section{Ethical consideration}

This article followed all ethical standards for carrying out research without direct contact with human or animal subjects.

\section{References}

Damasio, A., 1999, The feeling of what happens. Body and emotion in the making, Harcourt Brace \& Company, New York.

Daniels, J.D., 2018, 'Friedrich Schleiermacher: Pentecostal friend or foe?', Ecclesiology 14(1), 69-90. https://doi.org/10.1163/17455316-01401006

MacGregor, K.R., 2019, 'Friedrich Schleiermacher, founder of modern liberal theology', in Contemporary theology: An introduction (pp. 23-33), Zondervan, Grand Rapids, MI.

Masaeli, M. \& Sneller, R., 2019, 'Cosmic consciousness: Introduction', in M. Masaeli \& R. Sneller (eds.), Cosmic consciousness and human excellence: Implications for global ethics, pp. 2-14, Cambridge Scholars Publishing, Newcastle.

Mezei, B.M., 2019, 'Faith and reason', in L. Ayres \& M.A. Volpe (eds.), Oxford handbook of Catholic theology, pp. 55-71, Oxford University Press, Oxford.

Mouton, E., 1990, 'Faith, language and experience: An analysis of the feeling of absolute dependence', HTS 46(3), 345-358, viewed 21 October 2018, from https://www.ajol.info/index.php/hts/article/viewFile/148053/137560.

Reed, H., 2004, 'On “Friedrich Daniel Ernst Schleiermacher (1768-1834)"', viewed 21 October 2018, from http://people.bu.edu/wwildman/bce/mwt_themes_470_ schleiermacher.htm.

Roberts, R., 2016, 'Emotions in the Christian tradition', in The Stanford encyclopaedia of philosophy, viewed 20 October 2018, from https://plato.stanford.edu/archives/ win2016/entries/emotion-Christian-tradition.

Scarantino, A., 2018, 'Emotion', in The Stanford encyclopaedia of philosophy, viewed 20 October 2018, from https://plato.stanford.edu/entries/emotion.

Schleiermacher, F., 1799, On religion: Speeches to its cultured despisers, transl. J. Oman (1893), Trübner. Digitizing Sponsor MSN, London, viewed 20 October 2018, from https://archive.org/details/onreligionspeech.

Schleiermacher, F., 1830, Christian faith, transl. T.N. Tice, C.L. Kelsey \& E. Lawler (2016), Westminster John Knox Press, Louisville, viewed 21 October 2018, from https://onlinelibrary.wiley.com/doi/full/10.1111/moth.12363. 
Stewart, J., 2018, 'Hegel's criticism of Schleiermacher and the question of the origin of faith', Filozofia 73(3), 179-190.

Stoker, W., 2006, Is faith rational? Peeters, Leuven.

Ural, N.Y. \& Berg, A.L., 2019, 'From religious emotions to affects: Historical and theoretical reflections on injury to feeling self and religion', Culture and Religion 20, viewed 22 April 2019, from https://doi.org/10.1080/14755610.2019.1603168
Veldsman, D., 2014, 'With reasons of the heart before God. On religious experience from an evolutionary-theological perspective', NGTT 55(1), 425-441, viewed 20 October 2018, from ngtt.journals.ac.za/pub/article/download/534/554.

Ward, K., 2019, Religion in the modern world. Celebrating pluralism and diversity, Cambridge University Press, New York.

Wolfe, J., 2019, 'The eschatological turn in German philosophy', Modern Theology 35(1), 55-70. https://doi.org/10.1111/moth.12460 